\title{
Designing the (Most) Mobile University: The Centrality of International Student Mobility in Luxembourg's Higher Education Policy Discourse
}

\author{
Emilia Kmiotek-Meier ${ }^{\mathrm{a}}$ (1), Ute $\operatorname{Karl}^{\mathrm{b}}$ and Justin J. W. Powell ${ }^{\mathrm{c}}$ \\ ${ }^{\mathrm{a}}$ Institute of Geography and Spatial Planning, University of Luxembourg, 11, Porte des Sciences, \\ 4366 Esch-sur-Alzette, Luxembourg. \\ E-mail: emilia.kmiotek@uni.lu \\ ${ }^{b}$ Institute for Research and Innovation in Social Work, Social Pedagogy, Social Welfare, University of \\ Luxembourg, 11, Porte des Sciences, 4366 Esch-sur-Alzette, Luxembourg. \\ E-mail: ute.karl@me.com \\ ${ }^{\mathrm{c}}$ Institute of Education \& Society, University of Luxembourg, 11, Porte des Sciences, \\ 4366 Esch-sur-Alzette, Luxembourg. \\ E-mail: justin.powell@uni.lu
}

The nexus of national educational and migration policies and international student mobility (ISM) in Europe becomes strikingly visible in Luxembourg. ISM is central for higher education policy in Luxembourg, but also for larger questions of social integration and economic development. Based on a discourse analysis of the political debates surrounding the foundation of the University of Luxembourg in 2003, we analyse how and why ISM became a cornerstone of higher education policy in Luxembourg. Our findings reveal that, on the one hand, incoming student mobility - and the establishment of an international research university - was and is seen as a means of competing for the best and brightest, regionally and globally, and of securing human resources to satisfy a booming, internationalised labour market. On the other hand, outgoing student mobility has traditionally been viewed as the main mechanism to establish international networks across Europe and foster elites back home. Both incoming and outgoing student mobility are thought necessary to establish and maintain a competitive and sustainable knowledge economy. Reconstructing the underlying rationales behind the support for ISM as the key to higher education policy, we explain why Luxembourg currently has the highest proportion of ISM worldwide.

Higher Education Policy (2020) 33, 21-44. https://doi.org/10.1057/s41307-018-0118-4; published online 28 September 2018

Keywords: international student mobility; higher education policy; discourse analysis; knowledge economy; parliamentary debates; Luxembourg; Europe 


\section{Introduction: Internationalisation, Student Mobility, and a Small Country at the Heart of Western Europe}

In recent years, there has been a boom of contributions in the field of international student mobility $^{1}$ (ISM) (Hawkins and Jacob, 2011; Riaño and Piguet, 2016), being an integral part in the process of higher education internationalisation (Brooks, 2018). However, existing research on ISM has largely focused on a limited number of countries, such as the United Kingdom (Findlay, 2011; King and Findlay, 2012; King and Ruiz-Gelices, 2003; Tannock, 2013), the United States (Goodman and Gutierrez, 2011; IIE, 2017), and Australia (Adams et al., 2011; Hawthorne, 2014; Robertson, 2011). Although some authors have contributed perspectives from other, often European, countries (Ballatore and Ferede, 2013; Cairns, 2009; Lesjak et al., 2015; Urbanovič and Wilkins, 2013; Van Mol, 2014; Van Mol and Timmerman, 2014), geographical coverage is still punctual, with little evidence from some regions, including small (European) countries (however, see Koh, 2012; Urbanovič et al., 2015). This research gap is even more surprising regarding Luxembourg - analysed here - because the country boasts one of the highest ratios of outgoing and incoming degree ${ }^{2}$ and outgoing credit $^{3}$ students worldwide (OECD, 2014).

If country coverage is limited, so too are the topics covered. While issues such as the factors influencing students' decision-making processes, experiences, employability after graduation or intentions to stay in the host country have been broadly addressed (e.g. Beine et al., 2014; Coate, 2009; Netz, 2015; Wiers-Jenssen and Try, 2005; Wilken and Ginnerskov Dahlberg, 2017), less is known about policies' role in shaping the landscapes of ISM (inter)nationally (Riaño and Piguet, 2016) and how policy texts address the mobility phenomenon and mobile students (as a counter-balance to the main focus of ISM research: students' perspectives) (Brooks, 2018). Often 'student migration was analysed as part of individual decision-making' (Raghuram, 2013, 143), neglecting the fact that ISM takes place within broader frames, such as family, education system, state, and supranational contexts (but see Koh, 2012). Acknowledging the embeddedness of ISM in these wider contexts, we focus in this paper on the influence of higher education policy in shaping patterns of ISM, as '[t]he state is still required to be a promoter of

\footnotetext{
${ }^{1}$ We refer to international student mobility rather than to international student migration, although both of these terms are used in research. As stated by King et al. (2010, 6-7): 'Mobility implies a shorter time-frame for the movement, and a high probability of return, as in a typical Erasmus-type scheme (...). Less easy to label (...) are students who move for an entire degree programme (...). Such longer-term moves might better fit the conventional statistical definition of international migration (often predicated on a move lasting at least one year); but, again, the probability of return might be quite high'.

${ }^{2}$ Degree students pursue the whole cycle (Bachelor and/or Master and/or PhD) of their studies abroad.

${ }^{3}$ Credit students complete only a part of their studies abroad, receiving the diploma from their home university.
} 
internationalisation policies that enable national universities to participate in the global arena bringing benefits not only for themselves but also for the country in which they are based' (Horta, 2010, 77). Examining the under-researched case of Luxembourg, we base our analysis on documents that were part of parliamentary debates at the eve of the establishment of Luxembourg's public national research university in 2003. Oriented towards the Grand Duchy's unique context - small size, but simultaneously flourishing centre of European governance and international business, the University was founded upon the principles of internationality, multilingualism, and interdisciplinarity (Harmsen and Powell, 2018). Today, internationalisation is a key university strategy nearly everywhere (Fabricius et al., 2017; O'Connor, 2018) and ranks high among policymakers in strengthening competitiveness (Brooks and Waters, 2011). In fact, 'Outgoing mobility opportunities/learning experiences for students (study abroad, international internship etc.)' has been ranked the highest priority internationalisation activity among 604 European higher education institutions (Hudson, 2016). While universities all seek to benefit from student mobility, it 'might serve quite divergent purposes for (...) countries as a whole' (Rivza and Teichler, 2007, 460). Thus far, two main lenses to examine states' roles regarding ISM have been discussed: (1) filling in the gaps in financing higher education (Findlay, 2011) or facing public funds' cuts (Coate, 2009; Tannock, 2013), however this aim is not seen as a high priority among European institutions (Hudson, 2016, 15); and (2) the neo-liberal rationale in competing for the best and brightest to satisfy labour market needs (Thomas, 2017; Tremblay, 2005), as '[u]niversities are seen as a key driver in the knowledge economy' (Olssen and Peters, 2005, 313), and 'prime producers and diffusers of knowledge' (Horta, 2010, 63). Within the second line of argumentation, internationally mobile students have been objectified as needed highly skilled workers (Hawthorne, 2010; Koh, 2012; Mosneaga and Winther, 2013; Trilokekar and El Masri, 2016). The research has also focused on topics such as increasing host country's soft power ${ }^{4}$ (Haugen, 2013), resource generation (Lomer et al., 2018; Tannock, 2013) or attracting a skilled labour force (Mosneaga and Agergaard, 2012), thus underlying economically driven interests in hosting international students (Bolsmann and Miller, 2009) and answering the 'pressure to compete for resources and students' (Ordorika and Lloyd, 2015, 388). Luxembourg's extraordinarily internationalised labour market provides highly paid jobs that have made it among the most attractive in Europe, with 160,000 cross-border workers per day commuting from France, Belgium, and Germany (see Graf and Gardin, 2018). Thus, this article contributes to research literatures in higher education, policy studies, migration and geography, as well as labour markets. It also exemplifies the utility of analysing parliamentary debates,

\footnotetext{
${ }^{4}$ This term refers to 'the potential for obtaining policy objectives by shaping people's preferences rather than by means of military or economic coercion' (Haugen 2013, 317).
} 
especially for the rare case of the founding of a public national research university in the twenty-first century.

Regarding the meaning of ISM for the sending country, discussions have shifted from brain drain/gain to a global circulation of knowledge and skills perspective (Madge et al., 2015; Raghuram, 2013; Welch and Zhen, 2008). From an economic point of view, this focus emphasises that outgoing students may 'contribute to faster creation of new knowledge and help other people acquire skills without any direct costs' (Kim, 1998, 338, cited in Perna et al., 2015, 174) in the sending country. However, the argumentation of Adnett (2010, 633) suggests that 'internationalisation of education is one factor contributing to the unequal division of (...) benefits across countries'; Hudson $(2016,2)$ speaks about “"dark sides” of internationalisation'; both authors relating to negative consequences — the loss of human capital in sending countries, which are often poorer and less developed than the receiving ones.

Among OECD countries, Luxembourg has the highest ratio of both degree incoming students (as percentage of total tertiary enrolments in a country) $42 \%$, and degree outgoing students (as percentage of tertiary students holding Luxembourgish nationality) - 70\% (OECD, 2014, 349, 360; data from 2012), being similar to other small states, which 'send considerable numbers of students abroad for higher education' (Bray and Kwo, 2003, 422). Due to the multi-faceted approach to ISM (high numbers of incoming and outgoing; degree and credit mobility) in an era of internationalisation of higher education (Altbach and Knight, 2007; Dvir and Yemini, 2017; Findlay et al., 2012), Luxembourg has already far surpassed the 'regional regulatory' (Jayasuriya and Robertson, 2010) - the European benchmark of $20 \%$ students' mobility settled by the Leuven/ Louvain-la-Neuve Communiqué (2009). By contrast, for most other EU countries, this number seems to be an unrealistically ambitious target.

The aim of this contribution is to reconstruct the rationales that led to such high numbers of mobile students from and to Luxembourg, answering the plea for 'close-up analysis of the micropolitics of student mobility in specific geographical contexts' (Koh, 2012, 193). We focus on policy debates and rationales that determine ISM in Luxembourg while considering the country's unique history and geography. 'The situation of the University of Luxembourg is undoubtedly a unique one - that of a newly founded institution operating within a wider policy environment that has never before had to deal with the demands made by and on a full-fledged university' (Harmsen 2013, 21). Thus, by analysing the political debates surrounding the foundation of the University of Luxembourg — one of the most internationalised universities globally ${ }^{5}$ - we chart the ways in which ISM

\footnotetext{
5 The UL has been ranked number one in the World University Ranking 2018 in the category 'international outlook'. Three indicators are used to calculate this score: international-to-domesticstudent ratio, international-to-domestic-staff ratio and international collaboration (Times Higher Education, 2018).
} 
has become the keystone of higher education policy in Luxembourg, and how the political rationales behind it reflect broader debates and strategies to develop the country socially and economically.

We begin by describing the unusual ISM context in Luxembourg at the crossroads of Western Europe. Then, we describe the methodology (discourse analysis) and consecutive steps of data analysis. The subsequent section presents the findings, followed by a discussion and an outlook on further research.

\section{The context: ISM from and to Luxembourg}

In line with a long, significant tradition of outgoing student degree mobility, Luxembourg has always been a net exporter of degree mobility students. Due to the relatively late founding of the national university (2003), the University of Luxembourg (UL), those wishing to earn a university degree had to study abroad prior to 2003. Consequently, the country's own academic infrastructure - considering the country's socio-demographic development and labour market growth and aspirations remained underdeveloped for decades. Luxembourgish politicians have emphasised the importance of student degree outgoing mobility for a long time, especially for Luxembourgish industry, as the returning students bring not only knowledge and knowhow but also their networks from abroad (Rohstock and Schreiber, 2012). Differently than in other countries with high outgoing ratios of outbound ISM (e.g. Koh, 2012 on Singapore), the 'brain drain' phenomenon was never an issue in Luxembourg: '(...) it may be assumed that for Luxembourg this risk is minimised due to high salaries, good working and career conditions and a welfare and social security system' (KmiotekMeier and Karl, 2016, 111) as well as the hyperdiverse and multilingual society. In this context, the deliberations on the (non)sense of the foundation of a national university were directly linked to debates on the (dis)advantages of sending young people abroad to obtain a university degree (see Braband, 2015).

Even now, degree outgoing mobility has remained the main mode of obtaining tertiary education certification, with around $70 \%$ of national tertiary students enrolled abroad (OECD, 2014). Outgoing students are generously supported by the Luxembourgish state. The law from 2014 differentiates between four study allowances; including the so-called mobility scholarship, for both credit and degree outgoing students (1225€ per semester in 2018). Additionally, university fees up to $1850 €$ per semester are paid by Luxembourg. This form of support indicates also the willingness of the state to support academic education abroad, as the fees at the University of Luxembourg are only 200-400€ per semester (Cedies, 2018).

Incoming degree mobility was enabled by the UL's foundation and its development relies on international students; along with faculty and staff from

\footnotetext{
${ }^{6}$ Our own calculations based on national data on student allowances indicate a higher percentage: around $80 \%$. The discrepancies are not surprising due to non-compatible statistics on different levels (see Rivza and Teichler, 2007).
} 
abroad, due to 'limited pools of talent from which specialised personnel can be drawn' (Bray and Kwo, 2003, 420). In the Winter semester 2016/2017, 25\% of Bachelor, $70 \%$ of Master and $85 \%$ of $\mathrm{PhD}$ regular students (credit incomings excluded) held a foreign nationality (UL, 2016). To support students from nonEuropean third countries, the Ministry for Higher Education and Research provides 60 scholarships of $2100 €$ per semester, distributed through all study programmes according to the numbers of non-European students in those programmes. The directors of programmes decide - based on merit - who receives the scholarships (UL internal documents).

After more than a decade of the University's existence, both outgoing and incoming credit mobility have dramatically expanded. A key reason behind these impressive mobility numbers is that all undergraduate students must ${ }^{7}$ complete a stay abroad, which maintains the Luxembourgish tradition of outgoing degree mobility.

\section{Data and Methods}

The state's regulations and influence on higher education are strong in Luxembourg, a fact reflected in Luxembourg being ranked lowest in 'organisational autonomy' among 28 European countries (Bennetot Pruvot and Estermann, 2017, 41). To answer the posed research questions, we analyse the political debates on the eve of the foundation of the UL in the Chamber of Deputies, the Luxembourgish Parliament.

Since there is no systematically integrated nor fully-spelled-out policy at the national level relating to outgoing or incoming student mobility in Luxembourg, the debates prior to the establishment of the UL in 2002/2003 can be understood as a discursive event in which arguments, legitimation strategies, and political positions were exchanged with high density, such that the political strategies surrounding ISM became visible. Many aspects of higher education policy, including student mobility policies, are directly incorporated into the laws and regulations relating to the UL.

To understand the meaning of parliamentarian debates in Luxembourg and their position in the legislative procedures, two crucial aspects are: (1) the political culture in Luxembourg, and (2) the formal procedures involved in passing laws.

(1) An essential characteristic of Luxembourg's political culture is the 'search for consensus' at all levels and in all domains of national politics; especially prior to important decisions having potentially far-reaching consequences (Hirsch, 2008, 193). This is mirrored by the extra-parliamentarian roundtable discussions, traditionally a strong means in political decision-making processes (e.g. tripartite

\footnotetext{
7 'Students might skip the compulsory stay abroad, e.g. studying part time and having at the same time a permanent working position or care duties for children' (Kmiotek-Meier and Karl 2016, 112).
} 
between government, trade unions and employers), but also by how laws are discussed. (2) Laws must be initiated either by the Grand Duke or the parliament. A legal project ('projet de loi') is deposited at the parliament ('Chambre des Députés') after the Council of State ('Conseil d'Etat') has approved its accordance with the Constitution. After that, stakeholders may provide their opinions, contributing to the debate. These are mainly the trade unions and the employers' associations, and the six professional chambers (Schroen, 2008). The parliament votes on the final version of the law. ${ }^{8}$ It is exactly this debate that we will focus on, as most of the arguments present in society are expressed therein and the positions must be submitted in written form, which greatly facilitates discourse analysis.

We base our analysis on legal documents and published official statements within the parliamentarian debate regarding the foundation of the UL (2002/2003) (for a detailed list consult the Appendix). These sources are publicly accessible (in French) and consist of 14 pieces of documentation. Analysing political debates, and not only their results in form of laws, sheds light on the political rationale(s) and arguments that underlie the increasing focus on higher education and mobility. This provides a unique perspective on ISM.

The data analysis follows a discourse analytic approach inspired by Foucault's theoretical reflections and the sociology of knowledge (Keller, 2005; Schröder and Karl, 2017; Truschkat, 2012). In line with Foucault, discourses are understood as power/knowledge-formations that preconfigure action. By a 'system of formation' Foucault means

a complex group of relations that function as a rule: it lays down what must be related, in a particular discursive practice, for such and such an enunciation to be made, for such and such a concept to be used, for such and such a strategy to be organized. To define a system of formation in its specific individuality is therefore to characterize a discourse or a group of statements by the regularity of a practice (Foucault, 1972, 74).

The aim of the discourse analysis is thus to reconstruct the ways knowledge is produced and the underlying structures of how things are said (system of formation). Consequently, we aim to reconstruct how power is exerted, as discourses draw powerful boundaries between the reasonable/non-reasonable, the legitimate/illegitimate, the true/false, the visible/invisible, and transport a certain 'moral order' (Karl, 2014, 10). Concretely, we based the practical steps of analysis on grounded theory methodology (Charmaz, 2014). Firstly, we started with thematic coding searching for all sequences dealing with student mobility (credit/ degree and outgoing/incoming). This first step was followed by an in-depth analysis

\footnotetext{
${ }^{8}$ Regularly, there is a second vote. State Council, with the parliament, can opt to shorten the process; the Grand Duke has veto power.
} 
of selected extracts of the documents (based on the questions below) and a building of hypotheses, and through permanent comparison, the development of more theoretical concepts, i.e. the three lines of argumentation that will be presented below. All citations presented are originally in French and have been translated into English by the authors.

Three questions guided the discourse analysis: First, what is the taken-forgranted context, the diagnostic frame for society, and which prognosis for society is spelled out when discussing ISM? Second, how has ISM policy developed in Luxembourg? Three, which legitimation arguments are given in political strategies towards ISM, and what are the dominant lines of argumentation?

In regard to the debates, we analyse how these dominant lines of argumentation became a material reality through the Law of the University of Luxembourg that directly influences national ISM policies and practices in Luxembourg even today.

\section{Findings: lines of argumentation}

In the analyses, we extracted three major, yet interconnected, lines of argumentation used when discussing student mobility, and more generally the internationalisation of the future University. The topics those three lines of argumentation are related to were mentioned in every document analysed, showing their centrality for the Luxembourgish context. The first line of argumentation refers to the future (vision) of Luxembourgish society and is linked to concepts and topics such as knowledge society, future development of the country, innovation, international competition and labour force, discussed also in other regions (see e.g. Jöns and Hoyler, 2013; Mosneaga and Agergaard, 2012; Tannock, 2013; Tremblay, 2005), as '[i]nvestment in higher education is commonly considered a means to achieve innovation, increased productivity and enhanced national competitiveness' (Urbanovič and Wilkins, 2013, 374). The second line of argumentation refers to the current state and oscillates around keywords such as elites and sovereignty in higher education. The third line of argumentation reconstructed the territorial areas of internationalisation of the UL and underlies the two first lines of argumentation.

\section{Societal diagnostics and prognostics on the eve of the UL's foundation}

During the debates over the UL's foundation, one important focus was the development of Luxembourgish society and economy within European and global contexts. This point was already present in the first bill on the Foundation of the UL, presented by the Ministry of Culture, Higher Education and Research. In the opinions from the Chamber of Trades, the Chamber of Private Employees and the Chamber of Commerce there is the strongest - and a positive - reference to this aspect, in comparison with other bodies (see Appendix). The aim was to ensure success of the country in global competition and in the transformation to a 
knowledge society (e.g. 5059, 5-6). ${ }^{9}$ Investment in higher education was seen as a step towards diversification of the economy $\left(5059 \_9,13\right)$. In this regard, the to-befounded university was acknowledged as one of the key players in the knowledge economy (Olssen and Peters, 2005) and as a provider of innovation, in stark contrast to older sectors, such as the steelmaking industry $\left(5059 \_6,5\right)$. Targets included future economic needs and especially the development of human capital (e.g. 5059), which is congruent with 'the European Union's need to compete in the global sphere' (Dvir and Yemini, 2017, 198) and the European model of skill formation that emphasises economic aspects of education as crucial, such as employability and spatial (less than social) mobility (Powell et al., 2012). This logic of development and the necessity of selecting successful strategies, given international competition, was fundamental within the debates of the Luxembourgish Parliament:

Within the last decades, Luxembourg has undergone major changes, processes that continue in an accelerated way. It has become evident that Luxembourg must anticipate its economic and social development, that it must act before having to react, and thus must provide the best opportunities to develop in a competitive environment $\left(5059 \_4,10\right)$.

Others are even more explicit when they state:

It is important to prepare students rapidly and on the highest level for the numerous challenges posed by a society based on information and knowledge, the driving resource for our society in the coming years. (...) The new university project is situated, without a doubt, in a crucial phase of the country's economic and social evolution. The decisions to take will have a strong impact on future perspectives for future generations, which underlines the importance of this legal project (5059_6, 2-3).

Innovation was seen as a motor for economic, cultural, and social transformation $(5059$-9, 4). Especially in the area 'research and innovation', which is essential for economic development, the need for foreign talent, creativity, and human resources was explicitly named $\left(5059 \_4,5\right)$. The UL's foundation can thus be considered a strategic step for improving Luxembourg's position within the global competition for the best and brightest, acknowledging that 'international students are (...) prospective skilled workers in the globalising competition for talent' (Mosneaga and Winther, 2013, 181). Mobility is seen as an essential tool for becoming a strategic player in the European innovation space $(5059,21)$ underlining 'the

\footnotetext{
${ }^{9}$ Original sources used for discourse analysis cited in text are not listed in references but in Table 1 in Appendix.
} 
importance of human capital (...) as important inputs for innovation and for economic growth' (Romer, 1990, cited in Ganguli, 2014, 95).

Although with different ideas of how to define and legally regulate it, the rhetoric of student mobility as essential in this respect was utilised strongly among all actors:

Because of its embeddedness in the country, the profile of the University of Luxembourg is marked through the societal and economic needs of the latter [country]. The University contributes to: (...) b. the economic development: the promotion of cooperation between the University and the economy, the attraction of foreign economic and human resources, the development of new communication technologies, the promotion of entrepreneurial spirit (5059, 21).

Related to the sketched diagnosis and prognosis of society and its future needs, the new university seemed well-suited to 'prepare' the future labour force, thereby contributing to the country's economic (and societal) development. The UL was viewed as a means to diversify the economy and to integrate citizens from diverse cultural backgrounds, while the polity remains dominated by local elites. This line of argumentation is closely connected with the second one: building the country's elites and ensuring sovereignty in higher education.

\section{Contemporary internationalisation and the role of student mobility: elites} and sovereignty in higher education

Arguments about degree student mobility from Luxembourg have been tightly connected to securing growth within the Luxembourgish labour market and the stabilisation of the country's elites educated abroad. Luxembourgish student circles, situated mostly in the university towns of the neighbouring Greater Region $^{10}$ and across Western Europe, can especially be seen as a key instrument of elite formation. As the key positions in these circles are closely linked to established individuals and groups who lead Luxembourgish politics and industry, the circles function as boosters of students' future careers (Rohstock and Schreiber, 2012). In this light, the initiative of the UL's foundation questioned to some extent the strategy of sending young people abroad for tertiary education to build up the country's elites (see Braband, 2015). Arguments were thus exchanged in the parliamentarian debates if and how the UL would be able to construct and secure this elite formation and ensure that the state could continue to exert influence far beyond its size.

\footnotetext{
10 The Greater Region includes: Lorraine (FR), Rhineland-Palatinate (DE), Saarland (DE), Walloon Region (BE), Luxembourg and the German-speaking Communities of Belgium and pursues common strategies on different issues, e.g. spatial development, education, tourism, etc. (Grande Region, 2017).
} 
On the one hand, parliamentarians argued that a national university might be able to match the country's needs more appropriately $\left(5059 \_6,2\right)$, acknowledging that students (elites) educated abroad are exposed to host countries' economic and sociocultural specifics, thus, referring to 'soft power' (Haugen, 2013) foreign receiving countries may have on Luxembourgish elites. This line of argumentation shows the need for self-regulation of the curriculum and of vocational socialisation - here again to better meet the needs of the Luxembourgish labour market. The $\mathrm{UL}$ is viewed as a chance to take responsibility, regain sovereignty, and decide the future direction of higher education in the country $\left(5059 \_4,2\right)$.

At the same time, others point to the fact that a national university would also reduce the 'parasitical' attitude of sending young people abroad for tertiary education, thus taking advantage of other countries' higher education infrastructure while not investing in its own:

To let one's own youth be educated by foreign countries, sometimes thanks to bilateral agreements even less strict than for their own autochthonous population, is extremely comfortable and in consequence it can be characterised as a parasitical attitude $\left(5059 \_4,3\right)$.

Yet major doubts were expressed with regard to the development of young adults, as well as their skills and qualifications, if they were to not go abroad:

Additionally, and it has always been the argument put forward first, that the young were forced to leave their 'village' to organise themselves in an unknown and much broader milieu, and to measure themselves with colleagues from all horizons $\left(5059 \_4,4\right)$.

The Chamber of Civil Servants and Public Employees (5059_1, 2) expressed its concern regarding undermining the tradition of outgoing degree mobility in favour of keeping young people at home, indicating that the length of a stay abroad does make a difference. The importance of 'broad personal horizons' through higher education abroad has been discussed in the context of other small states, e.g. Macau (Bray and Kwo, 2003, 423).

Within this situation of ambivalence, a major point of discussion was the demand for obligatory student mobility. One suggestion was that the UL's students should spend a period of time abroad in each phase of the Bologna system, i.e. during their Bachelor, Master and doctoral studies. Doubts were expressed, suggesting that this might cause disruptive movements for the young people from both Luxembourg and (especially) abroad (5059_2, 2-3; 5059_9, 5). Therefore, only undergraduates are now required to spend at least one semester abroad, a compromise described as 'calming the debate'. Although the idea of going abroad was generally welcomed, there were doubts regarding 'forced mobility' expressed by the State Council: 
Another characteristic of the university to be created regards the obligatory mobility of the students, which is inscribed in its fundamental principles. The principle of mobility constitutes, without a doubt, a positive aspect for the opening of the minds of the students, Luxembourgish and foreign. (...) However, the State Council asks itself whether the forced character of this measure is not too rigid and should, in consequence, only concern the disciplines in which mobility is fundamental to training and later professional life $\left(5059 \_7,3\right)$.

The assumption of the debates on outgoing mobility as a tool to foster the internationally competitive knowledge society is that young people will return having gained new insights and established their international networks. This in turn will contribute to the economic and social development of the country. Taking advantage of the higher education infrastructure of other countries has been rather in focus while discussing ISM from less wealthy or less developed countries to more developed countries (Baláž and Williams, 2004; Woldegiorgis and Doevenspeck, 2015). This sheds light on the problem of a small country such as Luxembourg, which is extremely wealthy, but lacking the opportunities provided in fully developed and differentiated tertiary education systems. Using this strategy of investment, which relies on global higher education and international mobility, even micro states may exert influence via elite networks, supranational coordination, and business acumen far beyond their population size or land area, with Luxembourg and Qatar being paragon cases of such influence (Powell, 2014).

\section{What kind of internationalisation in Luxembourg?}

Thus far, our analyses have shown that the new to-be-formed university was viewed as a university aiming to serve an international public:

On top of the Luxembourgish specifics, the University of Luxembourg integrates itself above all in a European and international context. Completely recognising that Luxembourg has specific characteristics, the University is international before being national $(5059,21)$.

In these debates, two geographical areas were targeted for cooperation and recruitment of foreign students: the Greater Region as well as the EU and Europe. This focus shows that the implementation level occurs rather regionally, particularly with neighbouring countries. In the context of the new university's geographical embeddedness, also the aspect of language policy was discussed.

\section{The Greater Region}

It has been emphasised that it is necessary for Luxembourg to continue cooperating with neighbouring countries, especially within the framework of the Greater Region: 
Emilia Kmiotek-Meier et al.

An important number of universities exists within $200 \mathrm{~km}$ around Luxembourg. It would be senseless to compete with them or to ignore them. The UL must find synergies and complementarities with these institutions (5059_4, 5).

Not only cooperation, but also competition within this region, is of substantial importance for the UL. For degree incoming students, the UL competes with these other universities, indicating the rather regional dimension of the project.

\section{The EU and Europe}

Parliamentarian debates underlined that the UL should become a European university as the country itself is a key proponent of European integration, not least as an EU capital, being the site of the European Court of Justice and other EU institutions. Thus, the crossroads of research and teaching should revolve around European integration to strengthen existing structures in the country as well as the European dimension of the country's future $(1648,1)$. In fact, while there was no discussion about 'an' international university (although later named as such), there was clear interest in having a European university.

Although the notion of 'Europe' is used, what is less clear is the notion's exact definition. As the documents refer very often to the Treaty of Lisbon and the Bologna Declaration (5059), the EU is the assumed focus. Indeed, Luxembourg signed onto the Bologna process even before the UL's founding (Braband, 2015). Traditionally, outgoing degree (and now credit mobility) has been very EUoriented, with few students pursuing their education beyond the continent. Therefore, creating a university in line with the assumptions of the Bologna and Lisbon processes was the only feasible alternative $\left(5059 \_9,14\right)$ to give the UL 'a European and international character based on the history and the culture of Luxembourg' (5059_1, 2).

\section{Challenges and opportunities of multilingualism in university and society}

One explicitly discussed obstacle is the multilingualism of the University, with three official languages: German, French and English. ${ }^{11}$ Multilingualism was one of the six central founding principles of the UL (A - No. 149, Art. 3). For the hyperdiverse, multilingual Luxembourgish society, a multilingual labour force is a necessity. Although language skills are a crucial resource, prominent voices argued that creating a multilingual university could also undermine the recruitment of excellent candidates globally, as demanding fluency in too many languages would become a barrier for many potential students:

\footnotetext{
${ }^{11}$ Luxembourg has three official languages: Luxembourgish, French and German.
} 
Multilingual education constitutes an interesting axe, taking into consideration the linguistic situation of the country. However, it is an obstacle for recruiting foreign students who have not yet established their knowledge of the subject. It can thus represent a mortgage for the needed critical mass of students (5059_7, 3).

In light of ISM debates linked to language of instruction, non-English-speaking programmes may diminish students' readiness to study in Luxembourg, whereas the UL's French-speaking programmes may be appealing for students coming from other francophone countries (Lasanowski, 2011, 201ff.).

Indeed, the geographical embeddedness of the to-be-founded UL was discussed within the rationale named above. A vivid connection to the Greater Region is reflected by the high numbers of Luxembourgish students studying in its main university cities. Additionally, the largest group in Luxembourg's labour force is that of cross-border employees and workers from the Greater Region (Brosius et al., 2014). Thus, through the UL's creation it was assumed that a new labour force delivered to the country would be, at least partly, already familiarised with the national context during their study time (Hawthorne, 2010). Focusing on the EU may be, from an economic point of view, connected to the free movement of EU's citizens, greatly facilitating recruitment processes.

\section{Discussion: International Student Mobility as 'Central Planned Economy' in Luxembourg?}

After the debates analysed above had taken place in the Chamber of Deputies, the law on the University of Luxembourg was passed (A-No. 149). Two of the fundamental principles of the newly established University were its international character and cooperation with other universities and the obligatory mobility semester for all undergraduates. Hence, the continued tradition of educating young people abroad, and the international orientation and cooperation of the country were no longer simply debates but became national legislation.

The UL's foundation reflects a critical juncture for higher education policy in Luxembourg (barely existent before), in face of a long tradition of outgoing degree mobility for the vast majority of the country's educated decision-makers and elites. As our analysis shows, Luxembourgish policymakers decided not only to maintain or replace traditional degree outgoing mobility, but to complement it by incoming degree mobility, outgoing credit mobility, and, to a lesser extent, incoming credit mobility, emphasising ISM in Luxembourg as the key issue of the internationalisation of higher education policy.

Our analysis draws particular attention to the parliamentary debates prior to the establishment of Luxembourg's public research university, an accessible source to reconstruct the lines of argumentation and the specific rationales of ISM in 
Luxembourg. Such a methodological approach is especially relevant in countries in which arguments are not always immortalised in scientific and political texts. By analysing the parliamentary debates as a discursive event, in which many stakeholders were given voice, we situated ISM within the broader societal and economic context of Luxembourg, today the country with the highest ratios of ISM worldwide. Our contribution showed how the tradition of educating young people abroad together with the foundation of a new higher education institution reshaped the national political consensus, leading to an updated vision of ISM.

The mobility 'rule' itself has not been questioned by any of the actors involved in the discussion on the creation of the University; only the scope and the effort needed to introduce the obligatory stay abroad were discussed. Interestingly, even if the Bill on the Foundation of the UL (5059) did not mention any form of mobility beyond the outgoing credit mobility, especially degree mobility (both incoming and outgoing) were at issue within the mobility debates, e.g. the Chamber of Commerce focussed strongly on human capital and the 'war for talents' (5059_6). This focus of discussion showed clearly the needs of the small country and the ways the UL should contribute to the country's economic development. Moreover, the stances of different stakeholders revealed their general perspectives on the labour force in Luxembourg, e.g. the Chamber of Labour was pleading rather for educational opportunities on the lower and upper secondary levels, aiming for a high level of vocational education, but at the same time finding the idea to have a research university in the country attractive (5059_11).

In other countries, the added value of ISM from an economic perspective is seen in a possible two-step migration process securing the labour force (see e.g. Hawthorne, 2014 on Australia; Koh, 2012 on Singapore; Trilokekar and El Masri, 2016 on Canada), offering developmental help to economically weaker countries (see e.g. Adams et al., 2011) or financially supporting national higher education institutions (see e.g. Lomer et al., 2018 on the UK). Our analysis of the political debates in Luxembourg reveals two additional rationales. First, the development of the country's elites and their international network-building as strategies to develop a highly Europeanised country (with a European capital city) through outgoing and incoming mobility. Second, the participation in international knowledge-building and brain circulation. We showed that ISM policies in Luxembourg have always been, and are still, integral parts of strategies regarding the internationalisation, economic development and social integration of a country on its way to becoming a knowledge society - and among the fastest growing in Europe.

Building on 'traditional specifics of Luxembourg' $(5059,21)$, the experiences and expectations of outgoing degree mobility, specifically of building transnational networks and returning with foreign know-how, were transferred to the context of outgoing credit mobility. However, the 'coming to the country with new perspectives' argument is not seen in the debates as the deciding factor regarding incoming mobility. The incoming degree students are rather seen as human capital 
essential for the Luxembourgish labour market, indicating the dominance of the economic imperative (Bolsmann and Miller, 2009). They are not considered economically beneficial in a short-term perspective as payers of tuition fees (as these are quite modest) or consumers, but rather in longer-term perspective as future employees. This is especially true as the small country cannot satisfy all demands for a highly qualified labour force due to its small population, highly selective and stratified secondary schooling (Backes, 2018) and, thus far, limited investments in tertiary education (Bray and Kwo, 2003; Urbanovič and Wilkins, 2013).

Thus, it is even more surprising - given the potential of the UL and the discussion in the policy texts presented - that there is no favourable legislation to keep the student body educated in Luxembourg as valuable labour force in the country. Firstly, PhD students with a work contract at the UL must leave the UL after five years (unless they are granted a rare permanent position), a rule applied also to all scientific personnel without permanent contracts (based on national labour law). Secondly, there are stricter regulations for non-EU nationals than EU nationals who wish to pursue their career in Luxembourg after graduating from UL. However, the reformed immigration law from 2017 represents a crucial change compared to the 2008 law. The older law allowed a stay for the non-EU nationals of only up to 2 years after graduation, with no opportunity to prolong their stay; the new law eliminates such a time restriction for graduates who wish to remain in Luxembourg.

Furthermore, parliamentary debates noted that Luxembourg successfully attracts qualified workers with high salaries, yet that in the long run more should be offered to young people, as Luxembourg would not be the only country with needs for highly skilled workers as it transitions to a knowledge-based economy (Welch and Zhen, 2008, 522). Securing an adequate scientific and intellectual infrastructure, along with opportunities for personal development, were strategies discussed for attracting the best and brightest (5059_5,4). Those strategies are in line with research on factors shaping the attractiveness of the country of destination for foreign graduates (Geddie, 2013).

It was also underlined that to secure innovation, Luxembourg needs both incoming and outgoing mobility of talented students. Thus, we observe that incoming and outgoing mobility were discussed as two sides of the same coin, namely the socio-economic development of the country and its position within the Greater Region and Europe, hosting an EU capital city. Furthermore, targeting foreign degree students was linked to the fact that the UL's establishment should not encourage Luxembourgish students to refrain from studying abroad. Thus, wanting to maintain this tradition and also to reach a critical mass of students for the new university, it was necessary to directly recruit foreign youth to become regular students attending the new research university. 
Incoming credit mobility was not addressed as strongly as outgoing credit mobility. Thus, focussing on incoming degree mobility, additional strengths of taking in students for shorter stays abroad (e.g. intercultural learning) seemed to be of minor interest or even to have been overlooked in the Luxembourgish context. This might be grounded in the fact that incoming credit mobility is conceptualised as an exchange and does not directly fit into the dominant socio-economic rationale. Further, in a hyperdiverse multicultural society — and university — such as in Luxembourg, intercultural exchange is a dominant feature of daily life; it is not necessary to acquire such diversity and exchange through short-term mobility. Indeed, ironically, the most international student experience available for Luxembourg's youth is to stay home and attend the UL. Going abroad by itself is no guarantee to 'internationalise' Luxembourgish youth, as they often remain embedded in pre-established Luxembourgish networks (Rohstock and Schreiber, 2012). Moreover, similarities between Luxembourg and other small states are found not only in the proportion of youth educated abroad but also in very high return rates to take up well-paid jobs in the civil servant sector back home after graduation.

\section{Outlook}

A common limitation in ISM studies, also here, is the focus on one part of the complex processes surrounding ISM. Analysing solely parliamentary debates, we could not take into consideration the diverse perspectives of other groups, such as pupils, who would become the future 'clients' of the UL or the professionals who 'convert' policies into practice. Hence, future research could join the perspectives of the legislative bodies' planning policies with those of contemporary users who experience the outcomes of decision-making processes and in aggregate show whether the debates — and the principles explicated therein — were on target and whether the rationales have proven prophetic. Indeed, Mosneaga and Agergaard (2012) discuss how universities in Denmark manoeuvre between their structural characteristics and national policies in being agents of internationalisation of higher education; Trilokekar and El Masri (2016) point out the relevance of the front-line staff. This evidence shows clearly that the ISM field is much more than a simplified addition of perspectives of students, organisations, and countries' policymakers, as all actors involved in ISM are interconnected. Actions of one actor cause a reaction in those of the others, consistently influencing and transforming each other.

Furthermore, there has been little discussion in Luxembourg on the interlinkages between geographic and social mobility, which is similarly lacking in the Europewide Bologna process agreement (Powell and Finger, 2013). There is some evidence that there are systematic differences between those going abroad and those staying at home. Parents of those pursuing a degree abroad have higher 
educational attainment than those staying at home. However, the younger the students, the more acceptable is the alternative to study at home, even if not considered for oneself (Kmiotek-Meier, forthcoming). In contrast, the debate regarding securing elites in a fully Europeanised country by sending them abroad raises important questions of inequality. The UL, educating a hyperdiverse student body of socially selected Luxembourg residents and non-Luxembourgers, may simultaneously deepen existing social inequalities within Luxembourg as it makes a modest contribution to lessening them globally, given the low tuition fees and scholarships available to incoming international students. This should be the subject of future research and would contribute to the debate on the distinctive role of ISM (Sin, 2009), with the emphasis not on the question if but how somebody goes abroad (credit or degree).

Lastly, future research could analyse the situation in additional countries and regions (as the key literature discusses a limited range of countries, mostly English speaking), and further connect policy evaluation and the analysis of mobility practices. We addressed this nexus here by taking into account the particularities of a less-researched country, Luxembourg — a small and extraordinarily culturally and linguistically diverse state at the crossroads of Western Europe - as it developed its inaugural higher education policy. With relevance for a range of disciplines - including higher education policy, migration and mobility studies, as well as studies of labour market and social integration - this contribution also shows how discourse analyses of parliamentary debates uncover key legitimation arguments. In particular, in the rare case of a twenty-first century establishment of a public national research university presented here, we show differently ISM can be framed, which roles the state plays in the process of articulating the contributions of ISM, and even making ISM the key to higher education policy itself. Other countries that aspire to foster ISM and thus internationalise their universities and their labour markets may regard Luxembourg as a model as it has successfully designed the most mobile university.

\section{Funding}

This work was supported by the EU's Horizon 2020 research and innovation programme under Grant Agreement No. 64926: project MOVE 'Mapping mobility - pathways, institutions and structural effects of youth mobility in Europe'.

\section{Compliance with Ethical Standards}

Conflict of interest All authors declare that they have no conflict of interest. 
Emilia Kmiotek-Meier et al.

\section{References}

Adams, T., Banks, M. and Olsen, A. (2011) 'International Education in Australia: from aid to trade to internationalization', in R. Bhandari and P. Blumenthal (eds). International Students and Global Mobility in Higher Education, New York: Palgrave Macmillan, pp. 107-128.

Adnett, N. (2010) 'The Growth of International Students and Sconomic Development: Friends or Foes?', Journal of Education Policy 25(5): 625-637.

Altbach, P.G. and Knight, J. (2007) 'The Internationalization of Higher Education: Motivations and Realities', Journal of Studies in International Education 11(3-4): 290-305.

Backes, S. (2018) Heterogenität im luxemburgischen Schulsystem. Eine Mixed-Method-Studie zu Bildungsverläufen aus ungleichheitstheoretischer Perspektive [Heterogeneity in the Luxembourgish School System], Weinheim: Beltz Juventa.

Baláž, V. and Williams, A.M. (2004) ''Been There, Done That': International Student Migration and Human Capital Transfers from the UK to Slovakia', Population, Space and Place 10(3): 217-237.

Ballatore, M. and Ferede, M.K. (2013) 'The Erasmus Programme in France, Italy and the United Kingdom: Student Mobility as a Signal of Distinction and Privilege', European Educational Research Journal 12(4): 525-533.

Beine, M., Romain, N. and Ragot, L. (2014) 'Determinants of the International Mobility of Students', Economics of Education Review 41: 40-54.

Bennetot Pruvot, E. and Estermann, T. (2017) University Autonomy in Europe III. The Scoreboard 2017, Brussels: European University Association.

Bolsmann, C. and Miller, H. (2009) 'International Student Recruitment to Universities in England: Discourse, Rationales and Globalisation', Globalisation, Societies and Education 6(1): 75-88.

Braband, G. (2015) 'Ein günstiges Zeitfenster: Die Gründung der Universität Luxemburg und der Einfluss internationaler Entwicklungen im Hochschulbereich. [Favourable Timeframe: The Foundation of the University of Luxembourg and the Influence of International Development in the Higher Education]', Die Hochschule 24(1): 144-156.

Bray, M. and Kwo, O. (2003) 'Higher Education in Small Territories: Political Transition and Development in Macau', Higher Education Policy 16(4): 413-432.

Brooks, R. (2018) 'Higher education mobilities: a cross-national European comparison', Geoforum 93: 87-96.

Brooks, R. and Waters, J. (2011) Student Mobilities, Migration and the Internationalization of Higher Education, New York: Palgrave Macmillan.

Brosius, J., Ray, J.-C., Verheyden, B. and Williams, D.R. (2014) Wage Differentials Between Natives and Cross-Border Workers Within and Across Establishments. Esch-sur-Alzette, Luxembourg: Luxemburg Institute of Socio-Economic Research (LISER). Working Paper Series no. 2014-04. https://doi.org/10.2139/ssrn.2615809.

Cairns, D. (2009) Youth on the Move? Student Mobility and Immobility in Portugal and Northern Ireland. Lisbon, Portugal: Centro de Investigacao e Estudos de Sociologia. CIES e-Working Papers no. 74/2009.

Cedies (2018) Frequently Asked Questions, https://cedies.public.lu/fr/support/faq.html, accessed 24 July 2018.

Charmaz, K.C. (2014) Constructing Grounded Theory, London: SAGE.

Coate, K. (2009) 'Exploring the Unknown: Levinas and International Students in English Higher Education', Journal of Education Policy 24(3): 271-282.

Dvir, Y. and Yemini, M. (2017) 'Mobility as a Continuum: European Commission Mobility Policies for Schools and Higher Education', Journal of Education Policy 32(2): 198-210.

Fabricius, A. H., Mortensen, J., and Haberland, H. (2017) 'The lure of internationalization: paradoxical discourses of transnational student mobility, linguistic diversity and cross-cultural exchange', Higher Education 73(4): 577-595. 
Findlay, A.M. (2011) 'An Assessment of Supply and Demand-Side Theorizations of International Student Mobility', International Migration 49(2): 162-189.

Findlay, A.M., King, R., Smith, F.M., Geddes, A. and Skeldon, R. (2012) 'World Class? An Investigation of Globalisation, Difference and International Student Mobility", Transactions of the Institute of British Geographers 37(1): 118-131.

Foucault, M. (1972) The Archaeology of Knowledge: And the Discourse on Language (Translated by Alan Sheridan Smith), New York: Pantheon Books.

Ganguli, I. (2014) 'Scientific Brain Drain and Human Capital Formation After the End of the Soviet Union', International Migration 52(5): 95-110.

Geddie, K. (2013) 'The Transnational Ties That Bind: Relationship Considerations for Graduating International Science and Engineering Research Students', Population, Space and Place 19(2): 196-208.

Goodman, A.E. and Gutierrez, R. (2011) 'The International Dimension of U.S. Higher Education: Trends and New Perspectives', in R. Bhandari and P. Blumenthal (eds). International Students and Global Mobility in Higher Education, New York: Palgrave Macmillan, pp. 83-106.

Graf, L. and Gardin, M. (2018) 'Transnational Skills Development in Post-industrial Knowledge Economies: The Case of Luxembourg and the Greater Region', Journal of Education and Work 31(1): $1-15$.

Grande Region (2017) Strategié, http://www.granderegion.net/La-Grande-Region-en-bref/Strategie, accessed 13 February 2018.

Harmsen, R. (2013). 'The Challenges of the Contemporary University', in: M. Margue (ed.) Université du Luxembourg, 2003-2013, Luxembourg: University of Luxembourg, pp. 14-21.

Harmsen, R. and Powell, J.J.W. (2018) 'Higher Education Systems and Institutions, Luxembourg', in P. Teixeira and J. Shin (eds). Encyclopedia of International Higher Education Systems and Institutions, Dordrecht: Springer, pp. 1-5.

Haugen, H.Ø. (2013) 'China's Recruitment of African University Students: Policy Efficacy and Unintended Outcomes', Globalisation, Societies and Education 11(3): 315-334.

Hawkins, J.N. and Jacob, J.W. (2011) 'Series Editors' Introduction', in R. Bhandari and P. Blumenthal (eds). International Students and Global Mobility in Higher Education, New York: Palgrave Macmillan, pp. ix-x.

Hawthorne, L. (2010) 'How Valuable Is 'Two-Step Migration'? Labor Market Outcomes for International Student Migrants to Australia', Asian and Pacific Migration Journal 19(1): 5-36.

Hawthorne, L. (2014) 'Indian Students and the Evolution of the Study-Migration Pathway in Australia', International Migration 52(2): 3-19.

Hirsch, M. (2008) 'Organisierte Interessen, Kammern und Tripartite [Organised Interests, Chambers and Tripartite]', in W.H. Lorig (ed). Das politische System Luxemburgs. Eine Einführung, Wiesbaden: VS Verlag für Sozialwissenschaften, pp. 106-129.

Horta, H. (2010) 'The Role of the State in the Internationalization of Universities in Catching-up Countries: An Analysis of the Portuguese Higher Education System', Higher Education Policy 23(1): 63-81.

Hudson, R. (2016) 'Dominated by Economics? Evidence of Changing Drivers of Internationalization and Its Funding Within Higher Education Institutions in Europe', Higher Education Policy 29(1): 1-19.

IIE. 2017. Open Doors Report on International Educational Exchange 2016, New York: Institute of International Education.

Jayasuriya, K. and Robertson, S.L. (2010) 'Regulatory Regionalism and the Governance of Higher Education', Globalisation, Societies and Education 8(1): 1-6.

Jöns, H. and Hoyler, M. (2013) 'Global Geographies of Higher Education: The Perspective of World University Rankings', Geoforum 46: 45-59.

Karl, U. (2014) 'Rationalitäten des Übergangs als Rahmenkonzept: Diskursive Verortungen und Erkenntnisinteresse [Rationalities of Transition as a Theoretical Frame: Debates and Cognitive 
Emilia Kmiotek-Meier et al. Designing the (Most) Mobile University: The Centrality of International Student Mobility

Interests]', in U. Karl (ed). Rationalitäten des Übergangs in Erwerbsarbeit, Weinheim: Beltz Juventa, pp. 9-25.

Keller, R. (2005) 'Analysing Discourse. An Approach from the Sociology of Knowledge', Forum Qualitative Social Research 6(3). https://doi.org/10.17169/fqs-6.3.19.

King, R. and Findlay, A. (2012) 'Student Migration', in J. Rath (ed). An Introduction to International Migration Studies, Amsterdam: Amsterdam University Press, pp. 259-280.

King, R., Findlay, A. and Ahrens, J. (2010) International Student Mobility Literature Review Report to HEFCE, London, UK: Higher Education Founding Council of England.

King, R. and Ruiz-Gelices, E. (2003), 'International Student Migration and the European 'Year Abroad': Effects on European Identity and Subsequent Migration Behaviour', International Journal of Population Geography 9(3): 229-252.

Kmiotek-Meier, E. (forthcoming) Mobility as Normality? Student Mobility from Luxembourg from the Life Course Perspective.

Kmiotek-Meier, E. and Karl, U. (2016) 'Student Mobility in Luxembourg', in K. Hemming, F. Tillmann and B. Reißig (eds). Deliverable 2.4 - Final Work Package Report WP2 MOVE, pp. 111-121.

Koh, A. (2012) 'Tactics of Interventions: Student Mobility and Human Capital Building in Singapore', Higher Education Policy 25(2): 191-206.

Lasanowski, V. (2011) 'Can Speak, Will Travel: The Influence of Language on Global Student Mobility', in R. Bhandari and P. Blumenthal (eds). International Students and Global Mobility in Higher Education, New York: Palgrave Macmillan, pp. 193-209.

Lesjak, M., Juvan, E., Ineson, E.M, Yap, M.H.T and Podovšovnik Axelsson, E. (2015) 'Erasmus Student Motivation: Why and Where to Go?', Higher Education 70(5): 845-865.

Leuven/Louvain-la-Neuve Communiqué (2009). European Union. European Commission: Communiqué of the Conference of European Ministers Responsible for Higher Education, Leuven and Louvain-laNeuve, 28-29 April 2009. (IP/09/675). Retrieved from: http://europa.eu/rapid/press-release_IP-09675_en.htm.

Lomer, S., Papatsiba, V. and Naidoo, R. (2018) 'Constructing a National Higher Education Brand for the UK: Positional Competition and Promised Capitals', Studies in Higher Education 43(1): 134-153.

Madge, C., Raghuram, P. and Noxolo, P. (2015) 'Conceptualizing International Education', Progress in Human Geography 39(6): 681-701.

Mosneaga, A. and Agergaard, J. (2012) 'Agents of Internationalisation? Danish Universities' Practices for Attracting International Students', Globalisation, Societies and Education 10(4): 519-538.

Mosneaga, A. and Winther, L. (2013). 'Emerging Talents? International Students Before and After Their Career Start in Denmark', Population, Space and Place 19(2): 181-195.

Netz, N. (2015) 'What Deters Students from Studying Abroad? Evidence from Four European Countries and Its Implications for Higher Education Policy', Higher Education Policy 28(2): 151-174.

OECD (2014) Education at a Glance 2014: OECD Indicators, Paris: OECD Publishing.

O'Connor, S. (2018) 'Problematising strategic internationalisation: tensions and conflicts between international student recruitment and integration policy in Ireland', Globalisation, Societies and Education 16(3): 339-352.

Olssen, M. and Peters, M.A. (2005) 'Neoliberalism, Higher Education and the Knowledge Economy: From the Free Market to Knowledge Capitalism', Journal of Education Policy 20(3): 313-345.

Ordorika, I. and Lloyd, M. (2015) 'International Rankings and the Contest for University Hegemony', Journal of Education Policy 30(3): 385-405.

Perna, L., Orosz, K., Jumakulov, Z., Kishkentayeva, M. and Ashirbekov, A. (2015) 'Understanding the Programmatic and Contextual Forces That Influence Participation in a Government-Sponsored International Student-Mobility Program', Higher Education 69(2): 173-188.

Powell, J.J.W. (2014) 'International National Universities: Migration and Mobility in Luxembourg and Qatar', in B. Streitwieser (ed). Internationalisation of Higher Education and Global Mobility, Oxford: Symposium Books, pp. 119-133. 
Powell, J.J.W., Bernhard, N. and Graf, L. (2012) 'The Emergent European Model in Skill Formation: Comparing Higher Education and Vocational Training in the Bologna and Copenhagen Processes', Sociology of Education 85(3): 240-258.

Powell, J.J.W., and Finger, C. (2013) 'The Bologna Process's Model of Mobility in Europe: The Relationship of its Spatial and Social Dimensions', European Educational Research Journal 12(2): 270-285.

Raghuram, P. (2013) 'Theorising the Spaces of Student Migration', Population, Space and Place 19(2): 138-154.

Riaño Y, Piguet E (2016) International Student Migration. In: Warf B (ed) Oxford Bibliographies in Geography. Oxford University Press, New York. https://doi.org/10.1093/obo/9780199874002-0141

Rivza, B. and Teichler, U. (2007) 'The Changing Role of Student Mobility', Higher Education Policy 20(4): 457-475.

Robertson, S. (2011) 'Student Switchers and the Regulation of Residency: The Interface of the Individual and Australia's Immigration Regime', Population, Space and Place 17(1): 103-115.

Rohstock, A. and Schreiber, C. (2012) 'The Grand Duchy on the Grand Tour: A Historical Study of Student Migration in Luxembourg', Paedagogica Historica 49(2): 174-193.

Schröder, C. and Karl, U. (2017) 'On Being Guided - a Typology of Career Guidance in EU Discourses', British Journal of Guidance \& Counselling 45(3): 356-365.

Schroen, M. (2008) 'Parlament, Regierung, Gesetzgebung [Parliament, Government, Legislation]', in W.H. Lorig (ed.). Das politische System Luxemburgs. Eine Einführung, Wiesbaden: VS Verlag für Sozialwissenschaften, pp. 190-207.

Sin, I.L. (2009) 'The aspiration for social distinction: Malaysian students in a British university', Studies in Higher Education 34(3): 285-299.

Tannock, S. (2013) 'When the Demand for Educational Equality Stops at the Border: Wealthy Students, International Students and the Restructuring of Higher Education in the UK', Journal of Education Policy 28(4): 449-464.

Thomas, S. (2017) 'The Precarious Path of Student Migrants: Education, Debt, and Transnational Migration among Indian Youth', Journal of Ethnic and Migration Studies 43(11): 1873-1889.

Times Higher Education (2018) World University Rankings 2018, https://www.timeshighereducation. com/world-university-rankings/2018/world-ranking\#!/page/0/length/25/sort_by/rank/sort_order/asc/ cols/scores, accessed 20 May 2018.

Tremblay, K. (2005) 'Academic Mobility and Immigration', Journal of Studies in International Education 9(3): 196-228.

Trilokekar, R. and El Masri, A. (2016) 'Canada's International Education Strategy: Implications of a New Policy Landscape for Synergy Between Government Policy and Institutional Strategy’, Higher Education Policy 29(4): 539-563.

Truschkat, I. (2012) 'Zwischen Interpretativer Analytik und GTM - Zur Methodologie einer wissenssoziologischen Diskursanalyse [Between Interpretative Analysis and GTM - The Methodology of Sociological Discourse Analysis]', in R. Keller and I. Truschkat (eds.). Methodologie und Praxis der wissenssoziologischen Diskursanalyse: Band 1: Interdisziplinäre Perspektiven, Wiesbaden: VS Verlag für Sozialwissenschaften, pp. 69-87.

UL (2016) Key Performance Indicators, https://wwwen.uni.lu/university/official_documents, accessed 13 February 2018.

Urbanovič, J. and Wilkins, S. (2013) 'Internationalisation as a Strategy to Improve the Quality of Higher Education in Small States: Stakeholder Perspectives in Lithuania', Higher Education Policy 26(3): 373-396.

Urbanovič, J., Wilkins, S. and Huisman, J. (2015) 'Issues and Challenges for Small Countries in Attracting and Hosting International Students: The Case of Lithuania', Studies in Higher Education 41(3): 491-507. 
Emilia Kmiotek-Meier et al. Designing the (Most) Mobile University: The Centrality of International Student Mobility

Van Mol, C. (2014) Intra-European Student Mobility in International Higher Education Circuits. Europe on the Move, Basingstoke: Palgrave Macmillan.

Van Mol, C. and Timmerman, C. (2014) 'Should I Stay or Should I Go? An Analysis of the Determinants of Intra-European Student Mobility', Population, Space and Place 20(5): 465-479.

Welch, A.R. and Zhen, Z. (2008) 'Higher Education and Global Talent Flows: Brain Drain, Overseas Chinese Intellectuals, and Diasporic Knowledge Networks', Higher Education Policy 21(4): 519-537.

Wiers-Jenssen, J. and Try, S. (2005) 'Labour Market Outcomes of Higher Education Undertaken Abroad', Studies in Higher Education 30(6): 681-705.

Wilken, L. and Ginnerskov Dahlberg, M. (2017) 'Between International Student Mobility and Work Migration: Experiences of Students from EU's Newer Member States in Denmark', Journal of Ethnic and Migration Studies 43(8): 1347-1361.

Woldegiorgis, E.T. and Doevenspeck, M. (2015) 'Current Trends, Challenges and Prospects of Student Mobility in the African Higher Education Landscape', International Journal of Higher Education 4(2): 105-115.

\section{Appendix}

Table 1 List of analysed sources: English Translation [Original Title in French]

\begin{tabular}{|c|c|c|c|}
\hline Type of document & Documents & $\begin{array}{l}\text { Date of } \\
\text { publication }\end{array}$ & $\begin{array}{l}\text { Number } \\
\text { in text }\end{array}$ \\
\hline Bill & $\begin{array}{l}\text { Bill on Foundation of the University } \\
\text { of Luxembourg [Projet de Loi portant } \\
\text { création de l'Université du } \\
\text { Luxembourg] }\end{array}$ & 17.12 .2002 & 5059 \\
\hline \multirow{4}{*}{$\begin{array}{l}\text { Official opinions on the Bill of } \\
\text { Foundation of the University of } \\
\text { Luxembourg (5059) presented in the } \\
\text { Luxemburgish Chamber of Deputies } \\
\text { between March and July } 2003 \\
\text { [Chambre des Députés Session 2002- } \\
2003 \text { Projet de Loi portant création } \\
\text { de l'Université du Luxembourg] }\end{array}$} & $\begin{array}{l}\text { Opinion of Chamber for Civil } \\
\text { Servants and Public Employees [Avis } \\
\text { de la chambre des fonctionnaires et } \\
\text { employés publics] }\end{array}$ & 03.04 .2003 & 5059_1 \\
\hline & $\begin{array}{l}\text { Amendment of Commission of the } \\
\text { Higher Education, Research and } \\
\text { Culture [Amendements adoptés par la } \\
\text { commission de l'enseignement } \\
\text { supérieur, de la recherche et de la } \\
\text { culture] }\end{array}$ & 12.06 .2003 & $5059 \_2$ \\
\hline & $\begin{array}{l}\text { Amendment of Commission of the } \\
\text { Higher Education, Research and } \\
\text { Culture [Amendements adoptés par la } \\
\text { commission de l'enseignement } \\
\text { supérieur, de la recherche et de la } \\
\text { culture] }\end{array}$ & 01.07 .2003 & $5059 \_3$ \\
\hline & $\begin{array}{l}\text { Opinion of Chamber of Private } \\
\text { Employees [Avis de la chambre des } \\
\text { employés privés] }\end{array}$ & 26.06 .2003 & $5059 \_4$ \\
\hline
\end{tabular}


Emilia Kmiotek-Meier et al.

Designing the (Most) Mobile University: The Centrality of International Student Mobility

44

Table 1 List of analysed sources: English Translation [Original Title in French]

\begin{tabular}{|c|c|c|c|}
\hline Type of document & Documents & $\begin{array}{l}\text { Date of } \\
\text { publication }\end{array}$ & $\begin{array}{l}\text { Number } \\
\text { in text }\end{array}$ \\
\hline & $\begin{array}{l}\text { Opinion of Chamber of Trades [Avis } \\
\text { de la chambre des métiers] }\end{array}$ & 26.06 .2003 & 5059_5 \\
\hline & $\begin{array}{l}\text { Opinion of Chamber of Commerce } \\
\text { [Avis de la chambre de commerce] }\end{array}$ & 04.07 .2003 & 5059_6 \\
\hline & $\begin{array}{l}\text { Opinion of Council of State [Avis du } \\
\text { conseil d'état] }\end{array}$ & 10.07 .2003 & 5059_7 \\
\hline & $\begin{array}{l}\text { Report of Commission of the Higher } \\
\text { Education, Research and Culture } \\
\text { [Rapport de la commission de } \\
\text { l'enseignement supérieur, de la } \\
\text { recherche et de la culture] }\end{array}$ & 01.08 .2003 & 5059_9 \\
\hline & $\begin{array}{l}\text { Complementary report of Commission } \\
\text { of the Higher Education, Research and } \\
\text { Culture [Rapport complémentaire de } \\
\text { la commission de l'enseignement } \\
\text { supérieur, de la recherche et de la } \\
\text { culture] }\end{array}$ & 30.07 .2003 & 5059_10 \\
\hline & $\begin{array}{l}\text { Opinion of Chamber of Labour [Avis } \\
\text { de la chambre de travail] }\end{array}$ & 30.07 .2003 & $5059 \_11$ \\
\hline & $\begin{array}{l}\text { Motion of Chamber of Deputies } \\
\text { [Motion] }\end{array}$ & 17.07.2003 & 1648 \\
\hline & $\begin{array}{l}\text { Exemption from second constitutional } \\
\text { vote by the Council of State [Dispense } \\
\text { du second vote constitutionnel par le } \\
\text { conseil d'état] }\end{array}$ & 07.08 .2003 & $5059 \_12$ \\
\hline Law & $\begin{array}{l}\text { Law from 12th August } 2003 \text { on } \\
\text { Foundation of the University of } \\
\text { Luxembourg [Loi du } 12 \text { août } 2003 \\
\text { portant création de l'Université du } \\
\text { Luxembourg] }\end{array}$ & 06.10 .2003 & $\begin{array}{l}\text { A - } \\
\text { No. } 149\end{array}$ \\
\hline
\end{tabular}

No 5059_8 was not published 